\title{
Propagation of Santa Maria on Wild Pear Rootstock through Different Budding Techniques
}

\author{
Waqas Khan ${ }^{1 *}$, Ghulam Nabi', Muhammad Ali Khan ${ }^{2,3}$, Asad Ali Khan ${ }^{1}$, Muhammad Ilyas ${ }^{1}$, Saleem Khan ${ }^{4}$ and \\ Mehnaz Ghaffar ${ }^{4}$
}

${ }^{1}$ Department of Horticulture, The University of Agriculture Peshawar, Pakistan

${ }^{2}$ Department of Agriculture, Abdul Wali Khan University, Pakistan

${ }^{3}$ China Agriculture University, China

${ }^{4}$ Institute of Biotechnology and Genetic Engineering, The University of Agriculture Peshawar, Pakistan

Submission: October 28, 2017; Published: December 01, 2017

*Corresponding author: Waqas Khan, Department of Horticulture, The University of Agriculture Peshawar, Pakistan, Tel: +92 300 4168896;

Email: waqas.agri@yahoo.com

\begin{abstract}
Different budding techniques were practiced to propagate Santa Maria pear on wild pear (Pyrus pashia) rootstock under the agro-climatic conditions of Mansehra, at Agricultural Research Station Baffa Mansehra during 2015. Four different budding techniques i.e. T-budding, Patch budding, Chip budding and Ring budding were practiced to investigate their effects on different growth parameters after 60 days i.e., Days to sprouting, Bud take success, Budding growth, Stem thickness, No. of leaves and No. of branches. Minimum days to sprouting (26.3) and maximum bud take success $(69.3 \%)$, budding growth $(14.4 \mathrm{~cm})$, stem thickness $(0.4 \mathrm{~cm})$, No of leaves $(10.3)$ and No of branches $(2.2)$ were observed in plants budded by T-budding, while maximum days to sprouting (30.9) and minimum bud take success (40.3\%), budding growth ( $9.2 \mathrm{~cm}$ ), stem thickness $(0.1 \mathrm{~cm})$, No. of leaves (5.4) and No. of branches (1.3) were observed in plants budded by Chip budding. T-budding showed significant results among all of the parameters studied. It can be concluded that T-budding is a better option for better bud take success, days to sprouting, budding growth, stem thickness, No. of leaves and No. of branches.
\end{abstract}

Keywords: Budding; Wild pear Rootstock; Santa Maria; Bud Take Success

\section{Materials and Methods Experimental Location}

The experiment, propagation of Santa Maria on wild pear rootstock through different budding techniques was conducted at Agricultural Research Station Baffa, Mansehra, KP, Pakistan during 2015. The station is situated at 34.44 north latitude, 73.22 east longitudes and on 960 meters elevation above the sea level. The climate here is mild, and generally warm and temperate. The rainfall in Baffa is significant, with precipitation even during the driest month. According to Koppen and Geiger, the Mansehra climate is classified as CFA ( $\mathrm{C}=$ warm temperature, $\mathrm{F}=$ fully humid, $\mathrm{A}=$ hot summer). The average annual temperature in Baffa is 19.3 ${ }^{\circ} \mathrm{C}$. The rainfall here averages $1494 \mathrm{~mm}$ [1].

i. Plant Material: The plant material for rootstock was taken from Pyrus phasia locally known as Batangi and the Santa Maria was used as a scion variety. The rootstock and scion material was provided by Agricultural Research Station Baffa Mansehra.

ii. Soil Preparation: The soil was ploughed and five trolleys (about $10000 \mathrm{~kg}$ ) of well rotten Farm Yard Manure
(FYM) were applied per hectare. The seeds of wild pear were planted after treating it with fungicide i.e. (success). The plant to plant and row to row distance was kept at 7-15 cm and $70-90 \mathrm{~cm}$, respectively. Cultural practices such as irrigation, weeding and removal of fall sprouts below bud union were followed with regular intervals.

iii. Experimental Design: The experiment was designed in a randomized complete blocks design (RCBD) with 3 replications and 4 treatments. There were 20 plants per replication and 15 plants in each treatment.

iv. Experimental Procedure: The Fifteen months old wild pear (Pyrus pashia) seedlings having pencil size diameter were used as rootstocks. The one year old bud wood (Santa Maria) was selected from the pear orchard of Agriculture Research Station Baffa, Mansehra, KP, Pakistan. The bud wood was selected from vigorous plants in the pear orchard. The length of bud wood was $2.5 \mathrm{~cm}$ and the length of cut made in rootstock for inserting bud was $2.5-3 \mathrm{~cm}$. The budding height was $17 \mathrm{~cm}$. On the other hand, T, Patch, Chip and Ring 
budding techniques were practiced. The buddings during in the growing season were done on June 25th, 2015. Polythene tapes were used for wrapping. When the bud reached 10-15 $\mathrm{cm}$ in length, then the stock above union was removed.

v. Analysis: Data on sprouting were recorded after bud sprouting, while bud take success was recorded 2 months/ 60 days after budding. Observations on budding growth, stem thickness, No. of leaves and No. of branches were recorded after 60 days. Data as percentage were transformed and statistical analyses were applied over these transformed data by using Statistix 8.1 software. The LSD Test was used to indicate the differences between the average data.

vi. Parameters Studied Bud take success (\%): Data were recorded on bud take success and percent success was calculated with the help of following formula. Bud take success $\%=$ Total number of successful buds/ Total number of budded plants x 100

vii. Days to sprouting: Data were recorded on days taken to sprouting after budding and the mean was calculated.

viii. Budding growth (cm): Data were recorded on budding growth. The growth of the budding was measured by using a measuring tape. The mean was calculated.

ix. Stem thickness (cm): Data were recorded on stem thickness by using vernier caliper. The calibration of vernier caliper in $\mathrm{mm}$ was then converted into $\mathrm{cm}$. The mean was calculated.

x. Number of leaves plant -1: Data were recorded on No. of leaves plant -1 and the mean was calculated.

xi. Number of branches plant-1: Data were recorded on No. of branches plant -1 and the mean was calculated.

Table 1: Effect of different budding techniques on different growth parameters in wild pear.

\begin{tabular}{|c|c|c|c|c|c|c|}
\hline $\begin{array}{l}\text { Budding } \\
\text { Techniques }\end{array}$ & $\begin{array}{l}\text { Bud Take } \\
\text { Success }\end{array}$ & $\begin{array}{c}\text { Days to } \\
\text { Sprouting }\end{array}$ & Budding Growth (cm) & $\begin{array}{c}\text { Stem Thickness } \\
\text { (cm) }\end{array}$ & $\begin{array}{l}\text { Number of } \\
\text { Branches }\end{array}$ & $\begin{array}{l}\text { Number of } \\
\text { Leaves }\end{array}$ \\
\hline T-Budding & $69.3 \mathrm{a}$ & $26.3 \mathrm{a}$ & $14.4 \mathrm{a}$ & $0.4 \mathrm{a}$ & $2.2 \mathrm{a}$ & $10.3 \mathrm{a}$ \\
\hline Patch-Budding & $64.0 \mathrm{a}$ & $30.2 \mathrm{~b}$ & $12.4 \mathrm{a}$ & $0.3 \mathrm{ab}$ & $1.9 \mathrm{ab}$ & $6.8 \mathrm{~b}$ \\
\hline Chip-Budding & $40.3 \mathrm{~b}$ & $30.9 \mathrm{~b}$ & $9.2 \mathrm{~b}$ & $0.1 \mathrm{~b}$ & $1.3 \mathrm{c}$ & $5.4 \mathrm{~b}$ \\
\hline Ring- Budding & $60.0 \mathrm{a}$ & $29.4 \mathrm{~b}$ & $11.7 \mathrm{ab}$ & $0.2 \mathrm{~b}$ & $1.8 \mathrm{~b}$ & $6.5 \mathrm{~b}$ \\
\hline Significance & * & $*$ & $*$ & $*$ & $*$ & $*$ \\
\hline
\end{tabular}

a. Results: The overall data recorded on the below parameters are presented in (Table 1). However, the results of individual parameter are discussed below.

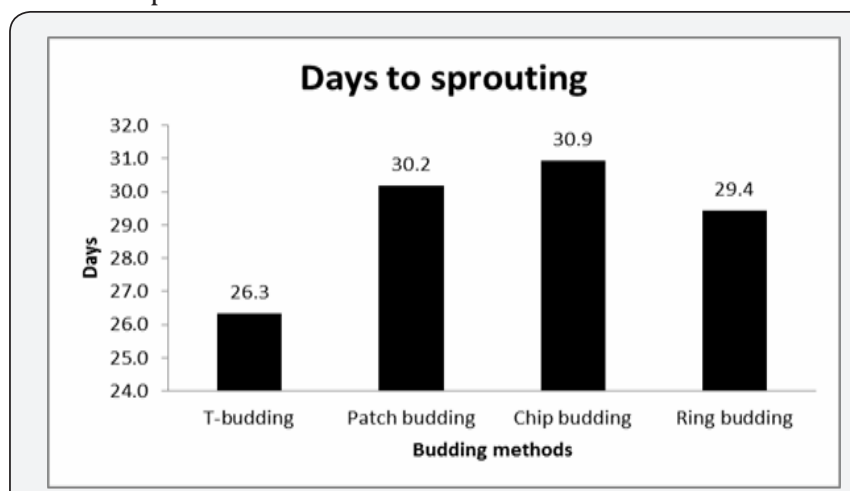

Figure 1: Figure shows the effect of different budding techniques on days to sprouting in wild pear.

i. Days to sprouting: The statistical analysis of data showed a significant variation of different budding techniques for days to sprouting (Figure 1) and (Table 1). Early sprouting (26.3 days) was observed in T-budding followed by ring budding (29.4 days), patch budding (30.2 days) and late sprouting was recorded in chip budding (30.9 days).

ii. Bud takes success (\%age): The data pertaining percent bud take success showed that the different budding methods had a significant effect on percent bud take success
(Figure 2) and (Table 1). Maximum bud take success (69.3\%) was recorded for the plants budded by T-budding, followed by the plants $(64.0 \%)$ budded by patch budding and the plants $(60.0 \%)$ budded by ring budding, while minimum bud take success $(40.3 \%)$ was obtained for plants budded by chip budding.

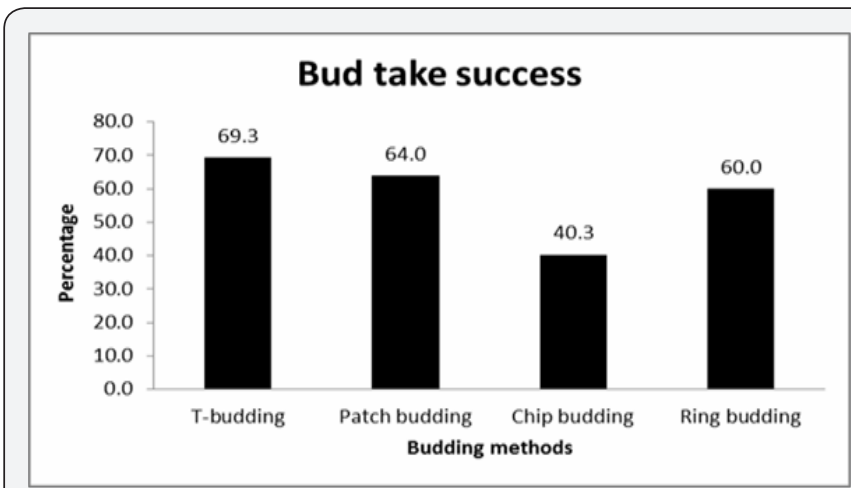

Figure 2: Figure shows the effect of different budding techniques on bud take success in wild pear.

iii. Budding growth (cm): The data pertaining to budding growth after 60 days showed that budding methods had significant effect on budding growth (Figure 3) and (Table 1). Mean values of budding growth revealed that maximum budding growth $(14.4 \mathrm{~cm})$ was recorded in plants propagated through T-budding, followed by plants $(12.4 \mathrm{~cm})$ budded by 
patch budding and plants $(11.7 \mathrm{~cm})$ budded by ring budding, while minimum budding growth $(9.2 \mathrm{~cm})$ was produced in plants budded by chip budding.

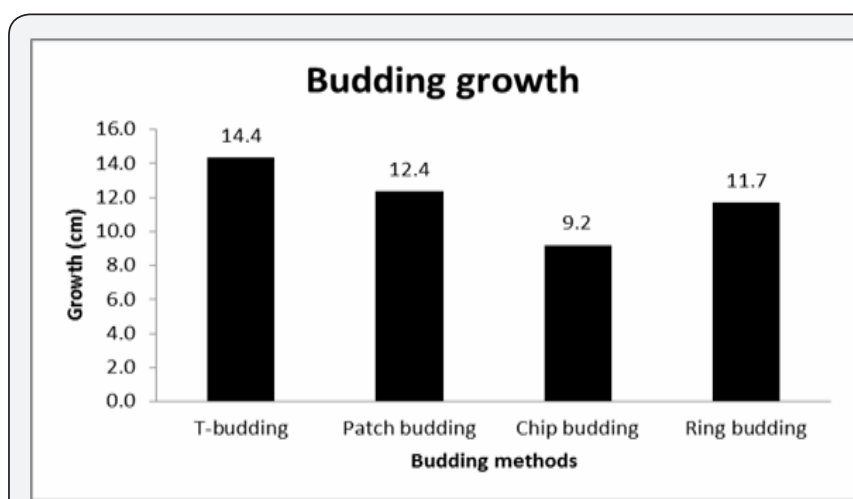

Figure 3: Figure shows the effect of different budding techniques on budding growth $(\mathrm{cm})$ in wild pear.

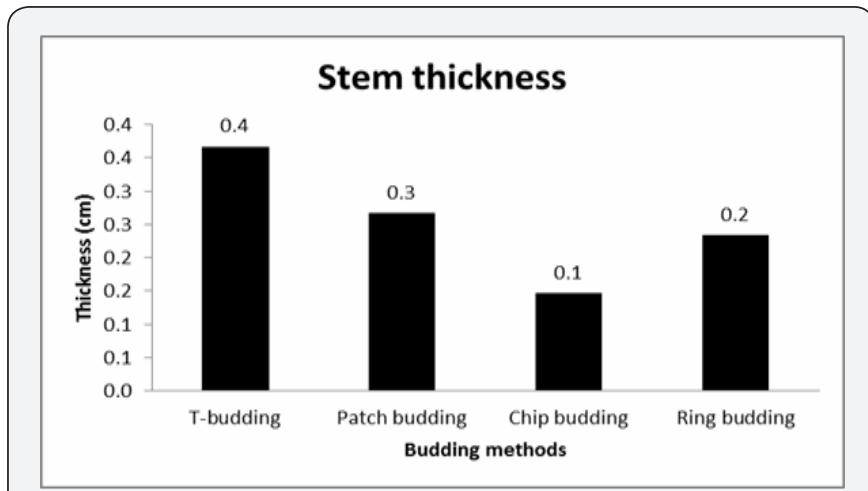

Figure 4: Figure shows the effect of different budding techniques on stem thickness $(\mathrm{cm})$ in wild pear.

iv. Stem thickness (cm): The data pertaining to stem thickness after 60 days showed that different budding methods had significant effect on stem thickness. Comparing the means of different budding methods in (Figure 4) and (Table 1). it is concluded that maximum stem thickness $(0.4$ $\mathrm{cm}$ ) was noted for plants budded by T-budding, followed by the plants $(0.3 \mathrm{~cm})$ budded by patch budding and the plants $(0.2 \mathrm{~cm})$ budded by ring budding, while the minimum stem thickness $(0.1 \mathrm{~cm})$ was obtained in plants budded by chip budding.

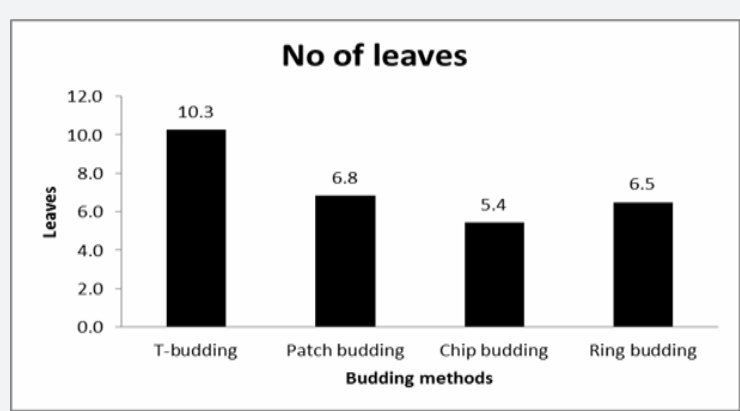

Figure 5: Figure shows the effect of different budding techniques on No. of leaves in wild pear. v. Number of leaves plant -1: The data recorded for the number of leaves plant -1 after 60 days showed that different budding methods had significant effect on number of leaves plant -1 (Figure 5) and (Table 1). Mean values of different budding methods showed that maximum number of leaves plant-1 (10.3) was noted for plants budded by T-budding, followed by the plants (6.8) budded by patch budding and the plants (6.5) budded by ring budding, while the minimum number of leaves plant -1 (5.4) was recorded in plants budded by chip budding.

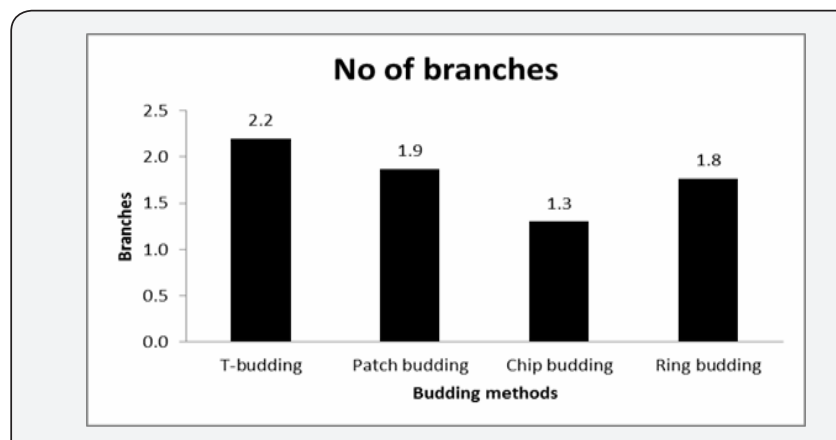

Figure 6: Figure shows the effect of different budding techniques on No. of branches in wild pear.

vi. Number of branches plant -1: The data obtained for the number of branches plant- 1 after 60 days showed that different budding methods had significant effect on the number of branches plant-1 (Figure 6) and (Table 1). Comparing the means of different budding methods, it is concluded that maximum number of branches plant-1 (2.2) were noted for plants budded by T-budding, followed by the plants (1.9) budded by patch budding and the plants (1.8) budded by ring budding, while the minimum no of branches plant-1 (1.3) were recorded for plants budded by chip budding.

b. Discussion: Maximum number of days to sprouting (30.9) were taken by plants budded by Chip budding, while minimum number of days to sprouting (26.3) were recorded in plants budded by T-budding. T-budding is a conventional method of propagation. T-budding leads to increased strength of rootstock and scion together and a lesser surface of wound is exposed to climatic conditions and as a result, healing at the bud union happens much better and quicker in T- budding, so therefore the minimum number of days to sprouting were observed in T-budding [2,3]. Data regarding bud take success revealed that maximum bud sprouting (69.3\%) was recorded for plants budded by T-budding and minimum bud sprouting (40.3\%) was noted in plants budded by Chip budding. It is due to the fact that from June to August the plants have high cell sap and T-budding require high cell sap and T-budding have directly contact with the cambium layer, while Chip budding have a chip of wood and therefore are not in directly contact with the cambium layer $[4,5]$.

The lower percent healing might be due to the climatic factor such as warm season or use of over mature bud wood or poor plant 
vigor [6]. It is revealed from result that maximum budding growth $(14.4 \mathrm{~cm})$ was noted when budding was done by T- budding, while the minimum budding growth $(9.2 \mathrm{~cm})$ was recorded when plants were budded by chip budding. It might be due to the stronger bud union and development of normal vascular tissues at the bud union which regulates the transport of water and nutrients and therefore enhance the active growth of scion [7]. Statistical analysis of the data revealed that different budding methods had significant effect on No. of leaves. Maximum number of leaves (10.3) was noted in plants budded by T-budding, while minimum number of leaves (5.4) were found in plants budded by Chip budding. This is due to the maximum budding growth in plants budded by T-budding which results in more number of leaves plant-1 as compare to plants budded by Chip budding which has resulted minimum budding growth.

Statistical analysis of the data revealed that different budding methods had significant effect on stem thickness. Maximum stem thickness $(0.4 \mathrm{~cm})$ was recorded on plants budded by T-budding, while minimum stem thickness $(0.1 \mathrm{~cm})$ was observed in plants budded by Chip budding. Maximum stem thickness might be due to the maximum budding growth in those plants budded by T-budding which contributed to the additional photosynthesis due to directly contact with the cambium layer and increase in growth and development of the stem [8]. Statistical analysis of the data revealed that different budding methods had significant effect on No. of branches. Maximum number of branches (2.2) were recorded in plants budded by T-budding and minimum number of branches (1.3) was noted in plants budded by Chip budding. It is evident that the number of branches has direct relation with number of leaves per plant. Plants having more branches will have more number of leaves and vice versa [9].

\section{Conclusion}

Among all of the budding techniques practiced on wild pear i.e. T, Chip, Patch, and Ring budding, the T- budding showed good results in all of the plant growth parameters i.e. Bud take success (\%), Days to sprouting, Budding growth, Stem thickness, No. of leaves and No. of branches plant -1 .

\section{Introduction}

The wild Himalayan pear (Pyrus pashia), is a small to medium size deciduous tree of the small and oval shaped crown with ovate, finely toothed leaves, attractive white flowers with red anthers and small pear-like fruits. It is a fruit bearing tree that is native to southern Asia. Locally, it is known by many names such as Batangi (Urdu), Tangi (Kashmiri), Mahalmol (Hindi) and Passi (Nepal) [10]. Pyrus pashia is distributed across the Himalayas, from Pakistan to Vietnam and from southern province of China to the northern region of India. It is also found in Kashmir, Iran and Afghanistan [11]. Pyrus pashia is a tolerant tree that grows on sandy loamy soil that is well drained. It is adapted to a precipitation zone that ranges from 750 to $1500 \mathrm{~mm} /$ year or more, and a temperature that ranges from -100 to $350 \mathrm{C}$ [12]. The average tree is 6 to 10 meters tall and 6 meters wide. Wooly or fuzzy leaves and young branchlets are a primary identification characteristic on young trees; both become smoother as the tree ages.

The leaves of a mature tree are characterized as simple, long-pointed, toothed, hairless and shining with an ovate to ovate-lanceolate shape the length of which ranges from 5 to 10 centimeters. Mature trees can have spiny branches with bark that is rough and quite dark, almost black in some cases. This can provide a dramatic backdrop to the tree's mass of bright white blooms in the spring and intense yellow foliage in the autumn. Flowers of pyrus pashia's, ranges 2 to $5 \mathrm{~cm}$ in diameter, are of white color that are slightly tinged with pink [10]. Flowers borne on spurs and each spur usually bear 3 to 11 flowers. Each flower has 5 sepals and 5 petals along with 15 to 20 red colored stamens that are slightly shorter than petals. They have inferior ovary with 3 to 5 loculed and each locule contains 2 ovules. Pyrus pashia is a fruit bearing tree. Its fruit is edible and characterized as being pome. It looks like the russet apple and has an astringent but sweet taste when ripe.

The shape of fruit is often described as oblate, ovoid, obovoid, oval or quince. On average the fruit diameter ranges from 1 to $4 \mathrm{~cm}$ and the height ranges from 2 to $5 \mathrm{~cm}$ [12]. The nutritive contents of fruit are about $6.8 \%$ sugars, $3.7 \%$ protein, $1 \%$ ash, $0.4 \%$ pectin. It also contains a low content of Vitamin C, about $1.2 \mathrm{mg}$ per 100g. Single fruit contain approximately 5 black colored seeds [10]. They are often shaped like a pear and are small, and light weight. They are approximately $7 \mathrm{~mm}$ long, $\mathrm{mm}$ wide, and weigh about $21 \mathrm{mg}$. Sexual reproduction and vegetative reproduction is common mean of reproduction in pyrus pashia. Seed stored under refrigerated conditions will remain viable for 2 to 3 years. In 2011-2012 total pear production in Pakistan was recorded 19071 tonnes while Khyber Pakhtunkhwa province produced 18431 tonnes [6]. In 2011-12 the area under cultivation for pear in Pakistan was 1942 hectares while in Khyber Pakhtunkhwa 1784 hectares.

The fruits of Pyrus pashia are edible and are used by everybody. They are very soft, gritty and highly perishable and cannot be transported, therefore, the possibility of their being marketed as fresh fruits is very rare. They are tasty even when dried and therefore be suitable for dehydration. Its wood is used for fuel as well as for making agricultural implements. The large limbs of this tree are used for fencing. The trees are also planted on the boundaries for making a live fence. Pyrus pashia is a suitable rootstock for pear. Different budding techniques were performed in pear, loquat, apple, to boost up its adoptability with local environment and improve its marketed quality. To introduce highly productive pear into a new growing area, a suitable locally adopted rootstock is required. In this connection, quick and successful growth response of scion (new pear cultivar) upon rootstock is very important. Therefore to test the ease and early successful growth in pear, various types of budding techniques such as T, Chip, Patch and Ring budding were evaluated. The 
present experiment was conducted at Agricultural Research Station, Baffa, Mansehra, KP, Pakistan. To check and compare T, Chip, Patch and Ring budding techniques in pear, Pyrus pashia (Batangi) and Santa Maria were used as a root stock and scion respectively [13].

\section{Objectives}

i. To investigate growth response of different budding techniques in pear (Pyrus pashia).

ii. To compare the early bud sprouting and percent growth rate in T, chip, patch and ring budding techniques in Pyrus pashia.

iii. To analyze bud success rate, growth interaction and compatibility of root stock (Pyrus pashia) and scion (Santa Maria)

\section{Recommendation}

Based on the above conclusion, the following recommendation is made, T-budding is the best for better growth of scion budded on wild pear.

\section{Acknowledgment}

Authors are greatly thankful to The Agricultural Research Station Baffa, Mansehra, KP, Pakistan for providing the platform and Dr. Muhammad Ali Khan, Assistant Professor, Department of Agriculture, Abdul Wali Khan University Mardan for his technical proof reading and revision of the manuscript. Moreover no conflict of interest is there among the authors.

\section{References}

1. Kottek M, J Grieser, C Beck, B Rudolf, F Rubel (2006) World map of the Koppen-Geiger climate classification updated. Meterologische Zeitschrift 15(3): 259-263.
2. Poniedzialek W, A Szczygiel, S Porebski, A Gorski (1997) Effect of Budding Dates and Types of Rootstock on Bud Establishment and Growth of One-Year Old Apple Trees of Two Cultivars. Zeszyty Naukowe Akademii Rolniczejim H Kollataja w Krakowie Ogrodnictwo, Poland.

3. Yazdani Z, J Mehrdad and S Majid (2015) Effect of Budding Method and Graft Union Height on Sweet Cherry Budding/Mahaleb Rootstock Compatibility. International Journal of Agronomy and Agricultural Research (IJAAR) 6(4): 229-232.

4. Celık H, H Zengınbal, M Ozcan (2006) Effect of Budding Performed by Hand and With Manual Grafting Unit on Kiwifruit Propagation in the Field. Hort Sci (Prague) 33(2): 57-60.

5. Webster A D (1997) A Brief Review of Pear Rootstock Development. In VII International Symposium on Pear Growing 475 pp. 135-142.

6. Shah M A, A Nawaz, A U Rehman, J U Rehman (2013) Morphological Study of Different Stone Fruit Species Budded on Peach Rootstock Under Agro-Climatic Conditions of Mansehra, Pakistan. Sarhad Journal of Agriculture Sarhad J Agric 29(4): 543-546.

7. Ahmad S, M Munir, N Bostan F Rabi (2015) Effects of Budding Methods and Time Intervals on Bud Take Success in Seedless Guava (Psidium Guajava L). ARPN Journal of Agricultural and Biological Science, Pakistan 10(4): 146-151.

8. Zenginbal H, M Ozcan, A Haznedar, A Tea, T Demir (2007) Comparisons of methods and time of budding in kiwifruit (Actinidiadeliciosa $\mathrm{A}$ Chev). International Journal of Natural and Engineering Sciences 1: 23-28.

9. Ali J J, F M H Salieh, I M Noori (2012) Utilization of Wild Pears Rootstocks as a Natural Resource for Loquat Production Under Rainfed Condition in Sulaimani Governorate. Tikrit University Journal for Humanities 19(3): 1-11.

10. Parmar C, M K Kaushal (1982) Pyrus pashia Buch \& Ham, In: Wild Fruits. Kalyani Publishers, India p. 78-80.

11.Zamani A, F Attar, M R Joharchi (2009) Pyrus pashia (rosaceae), a new record for the flora of Iran. Journal of botany 15(1): 72-75.

12. Sheikh M I (1992) Pyrus Pashia. Trees of Pakistan MINFA pp. 5-142.

13. Agri Stat Pak (2012-13) Plums Ministry for Food, Agriculture and Livestock, Economic Wing, Pakistan. Table 53. P. 97.

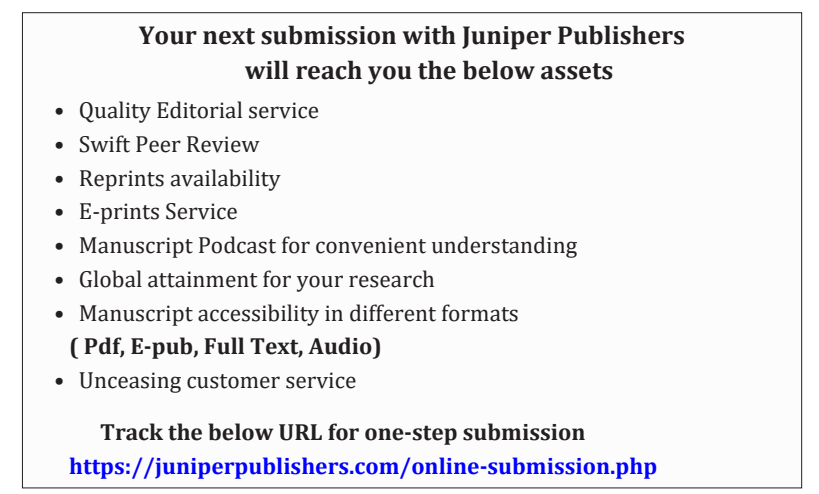

